\title{
Adalet ve Kalkınma Partisi’nin Siyasi Partilerin Doğuş Teorileri, Tipolojileri ve Kurumsallaşmaları Açısından Değerlendirilmesi
}

\author{
Evaluation of Justice and Development Party in Terms of Birth Theories, Typologies and \\ Institutionalization of Political Parties
}

İsmail ŞÜKÜR

Doktorant, Sakarya Üniversitesi, SBE,

Siyaset Bilimi ve Kamu Yönetimi A.B.D., ismail.sukur@ogr.sakarya.edu.tr

https://orcid.org/0000-0003-4517-2933
Makale Başvuru Tarihi: 17.10.2020

Makale Kabul Tarihi: 20.12.2020

Makale Türü: Araştırma Makalesi

\section{Anahtar}

Kelimeler:

Ak Parti,

Doğuş Teorileri,

Parti Tipolojileri,

Kurumsallașma,

Keywords:

Ak Parti,

Birth Theories,

Party Typologies,

Institutionalization,

\section{ÖZET}

Bu çalışmanın amacı, Adalet ve Kalkınma Partisi'ni (Ak Parti) kuruluşundan cumhurbaşkanlı̆̆ hükümet sistemine kadar geçen zaman diliminde siyasi partilerin doğuş teorileri, tipolojileri ve kurumsallaşma bağlamında incelemektir. Ak Parti, bahsi geçen teorik ölçütler çerçevesinde nitel araştırma yöntemine bağll olarak ilgili literatürün taranmastyla değerlendirilecektir. Kadro ve kitle partisi tipolojisinin bazı özelliklerini gözlemlemek mümkün olmasına rağmen bu çalışmanın bulgularına göre Ak Parti, Duverger'in kadro ve kitle partisi tipolojisine tam olarak benzememektedir. Türkiye'de 2000'li yılların başındaki siyasi ortam ve partilerin doğuş teorileri birlikte değerlendirilirse, Ak Parti bir sosyal bütünleşme partisi olarak tanımlanabilir. Türk sağının ideolojik çeşitliliği ve merkez să̆ parti siyasetinin esnekliği bă̆lamında Ak Parti, hepsini yakala partisi olarak değerlendirilebilir. Ak Parti kurumsallaşma kriterleri açısından örgütsel niteliklerin değerlendirilmesi bağlamında genç bir parti olarak tanımlanabilir. Ancak liderin karizmatik otoritesinin kurumsallaşma sürecini gölgelediğini gözlemlemek mümkündür.

\section{ABSTRACT}

The purpose of this paper is to study the Justice and Development Party (Ak Parti) from its establisment to the presidential government system in the context of the political parties' birth theories, typologies and institutionalization. Ak Party will be evaluated by scanning the relevant literature based on the qualitative research method within the framework of the mentioned theoretical criteria. According to the findings of this study, even though it is possible to observe some characteristics of cadre and mass party typology, Ak Parti is not completely similar to Duverger's cadre and mass party typology. If Turkey's political landscape at the beginning of 2000's and the parties' birth theories are evaluated together, Ak Parti would be defined as a social integration party. In the context of the ideological diversity of the Turkish right and the flexibility of the center-right party politics, Ak Parti could be considered as a catch-all party. Ak Parti could be defined as a young party in the context of evaluation of organizational qualifications in terms of institutionalization criteria. However, it is possible to observe that the leader's charismatic authority overshadows the institutionalization process. 


\section{GIRİŞ}

Siyasi partiler, "halkın desteğini sağlamak suretiyle devlet mekanizmasının kontrolünü ele geçirme veya sürdürmeye çalışan, sürekli ve istikrarlı bir örgüte sahip siyasal topluluk" (Özbudun, 1977:2) olarak tanımlanmaktadır. Tarihsel gelişim sürecine bakıldığında, genel oy ilkesinin kabulünden sonra partilerin niteliğinde gerçekleşen değişimleri gözlemlemek mümkündür. Genel oy ilkesinin kabulünden önce, Duverger'in (1974) parti yapısını esas alan tanımlaması dikkate alınacak olursa, parlamento içindeki seçkin bir zümrenin iktidarı ele geçirmek üzere örgütlendiği kadro partileri dikkat çekmektedir.

Genel oy ilkesinin kabulünden sonra, toplumun geniş kesimlerinin siyasallaşmasını sağlamak üzere, kitle partileri de sürece dâhil olmuştur. Teorik önermeler pratik uygulamaların tahlili sonucunda ortaya çıktığından, siyasi partiler; toplumdaki ekonomik, siyasal, kültürel gelişmelerin, ilgili devletin yönetim ve seçim sisteminin, toplumdaki kültürel, siyasal, ideolojik ayrımların yansımasıdırlar. Bu sebeple partilerin tahlili, içinde bulunulan tarihsel bağlam dikkate alınmadan yapılmamalıdır. Neredeyse bir asrı geçen süredir partiler üzerine yapılan çalışmalar, bugünkü partilerin; kuruluş amaçlarını, yapısını, örgütlenme tarzını, ideolojisini tahlil etmede yol göstericidir. Ancak günümüzde partilerin örgütlenişinde ve bir örgüt olarak kendi toplumuna karşı yürüttüğ̈̈ politikalarda; hem küresel ölçekte meydana gelen değişimlerin, hem de ülkenin içinde bulunduğu özgün durumun etkisi söz konusudur.

21. yüzyılın hemen başında Türkiye'de kurulan Ak Parti'nin de bu doğrultuda ele alınması gerekir. Bu çalışmada Ak Parti; siyasi partilerin doğuş teorileri, parti tipolojisi ve kurumsallaşma ölçeğinde nitel araştırma yöntemi (Punch, 2014; Miles ve Huberman, 2015) çerçevesinde değerlendirilmiştir. Öncesinde ise partinin kuruluş süreci, kurucu kadrosu, partinin ortaya çıkışına yol açan faktörler ve ideolojik kimliği kısaca değerlendirilecektir.

Çalışma, partinin kuruluş sürecinden Cumhurbaşkanlı̆̆ı Hükümet Sistemine kadar olan zaman dilimini kapsamaktadır. Bu değişiklikle birlikte öteden beri Türkiye'de varlığını sürdüren siyasal sistemde köklü bir reform gerçekleşmiştir. Yeni yönetim sistemi doğrultusunda Türkiye'de parti sisteminin ve buna bağlı olarak parti tipolojisinin de değişiklik göstereceği öngörülerek yeni hükümet sisteminin uygulandığı dönemde Ak Parti'nin tipolojik özellikleri çalışmanın kapsamı dışında tutulmuştur. Çalışmanın parti incelemelerinde sistematik bir yaklaşım kullanılabilmesi için yol gösterici olacağı düşünülmektedir.

\section{AK PARTI'NIN KURULUŞU VE SIYYASI İDEOLOJISI}

Ak Parti 14 Ağustos 2001'de Recep Tayyip Erdoğan önderliğinde kurulmuştur. Kurucu üyeleri arasında yer alan başlıca isimler; Ali Babacan, Ayşe Böhürler, Binali Yıldırım, Burhan Kuzu, Güldal Akşit, Cüneyd Zapsu, Murat Mercan, Hayati Yazıcı, Mevlüt Çavuşoğlu ve Nurettin Canikli'dir.

Millî Görüş geleneğinin o dönemdeki son partisi olan Fazilet Partisi içinde; gelenekçiler ve yenilikçiler adında iki grup oluşmuştur. Yenilikçiler, Abdullah Gül etrafinda toplanmışlar ve Gül'ü Fazilet Partisi genel başkanlığına taşımak istemişlerdir. Bu girişim başarısızlıkla sonuçlanmış, Fazilet Partisi kapatılmış ve Yenilikçiler, farklı bir parti kurma konusuna yoğunlaşmışlardır. Sonrasında Gelenekçiler, Recai Kutan'ın önderliğinde Saadet Partisi'ni, yenilikçiler ise Recep Tayyip Erdoğan önderliğinde Adalet ve Kalkınma Partisi'ni kurmuşlardır.

Ak Parti, kurulmasının ardından ilk girdiği Kasım 2002 seçimlerinde $\% 34$ oy almış ve 363 milletvekili ${ }^{1}$ seçtirerek tek başına hükümeti kurmuştur. Recep Tayyip Erdoğan "siyasi yasaklı" olduğundan Başbakanlık görevini Abdullah Gül üstlenmiştir. 2003 tarihinde Siirt'te yenilenen seçimlerin ardından milletvekili seçilen Recep Tayyip Erdoğan, başbakanlığı Abdullah Gül'den devralmıştır.

Ak Parti'nin ve lideri Erdoğan'ın Millî Görüş gömleğini çıkardığı yönündeki beyanatları ve yenilikçiler olarak İslam'1, siyasal söylemin odağına yerleştirmedikleri iddiası, siyasal meşruiyet oluşturmada kullanılan başlıca söylemlerdir. Bu süreçte Ak Parti'nin siyasal düzlemde kendine yer edinmesinde uyguladığı önemli politikalar ise Avrupa Birliği uyum sürecinin hızlandırılması, Kıbrıs müzakereleri ve ekonomik reformlardır. Öyle ki parti kendi meşruiyetini toplum nezdinde sağlama almadan, kendi tabanından gelen başörtüsü yasağının kaldırılması,

1 https://www.resmigazete.gov.tr/eskiler/2002/11/20021110.htm\#5 (Erişim Tarihi: 10.12.2020). 
katsayı mağduriyetinin giderilmesi gibi talepleri, kurumlar arası uzlaşma gerekçesiyle ötelemiştir (Erdoğan M., 2011).

Kurumsal meşruiyetin sağlanmasında gerekli olan bir diğer konu ise partiye siyasal bir ideoloji belirlemektir. Bu süreçte partinin hem geleneği önemseyen hem de yeniliğe açık olan yapısı ön plana çıkarılmaya çalışılmıştır. Bu durumda partinin siyasal ideolojisini tanımlamada "muhafazakâr demokrat" kavramı kullanılmaya başlanmıştır. Bu kavramı partinin kimliğiyle eşleştirmek için 2004 yılında "Uluslararası Muhafazakârlık ve Demokrasi Sempozyumu" düzenlenmiştir. Erdoğan burada yaptığı açılış konuşmasında din adına siyaset yapmanın dine zarar vermek olduğunu ifade etmiştir. Erdoğan'a göre (2004:12); “toplumun küçümsenmeyecek bir kesimi; geleneği dışlamayan bir modernlik, yerelliği kabul eden bir evrensellik, manayı reddetmeyen bir rasyonellik, köktenci olmayan bir değiş̧im istemektedir". Geleneksel değerlerle modern kavramların yumuşak birlikteliğinin ifadesi olan bu anlatımla, partinin muhafazakâr kimliğiyle "modernleşmenin gelişmeci yaklaşımı" bir araya getirilmeye çalışılmaktadır. Ancak modern değer ve kurumların savunulması muhafazakârlığın değil yeni muhafazakârlığın yaklaşımına daha uygundur. Muhafazakâr siyaset gelenekseli moderne tercih ederken, yeni muhafazakârlık modern şartlara uyum sağlamaya çalışmaktadır (Erler, 2007). Bu noktada muhafazakârlığı ${ }^{2}$ da kısaca tanımlamak gerekir.

Muhafazakârlı̆̆ın özünü; geleneksel kurumlara ve değerlere saygı, mevcut toplumsal işleyişin radikal ve tepeden inmeci değiştirilmesine karşı olma, toplumsal değişimin kendiliğinden gerçekleşmesine verilen önem oluşturur. "Tarihten, dinden, gelenekten bağımsız rasyonalist siyasetin aksine muhafazakâr, genellikle ılımlı ve tedrici değişimi öngören bir siyaseti savunur" (Özipek, 2004:85). Bu çerçevede Ak Partili siyasetçilerin muhafazakâr demokrat kimliği sahiplenerek İslamcı benliği geri plana çekmeyi amaçladıkları iddia edilebilir. Muhafazakâr demokrat kimlik, siyasal İslami kimliğin yerine ikame edilmeye çalışılmıştır.

Ak Parti'nin muhafazakâr demokrat kimliği benimsenmesini partinin o dönemki ideoloğu olarak gösterilebilecek Akdoğan (2004:18-19) şöyle izah etmiştir;

“AKP'nin muhafazakâr demokrasi kavramıyla yapmaya çalıştı̆̆ tür getirmek değil, bu terkip altında kendisine yeni bir kulvar açmaktt. Böyle bir kavram üretmek birkaç açıdan önem taşımaktadır: Siyaseti normalleştirmek ve gerçekçi bir zemine oturtmak, müstakil bir muhafazakâr parti ve kuşatıcı bir siyaset tarzı üretmek."

Bunun ardından Akdoğan (2004:18-20) bu kavramları tek tek açıklamıştır. Siyaseti normalleştirmek’ten kastedilen; "geleneği dişlamayan bir modernlik, yereli kabul eden bir evrensellik, köktenci olmayan bir değişim vurgusu"dur. "Müstakil bir muhafazakâr parti üretmek"ten kasıt, muhafazakârllğı merkez sağ partilerin içinde bir damar olmaktan çıkartıp, siyasetin ana gövdesi ve lokomotifi haline getirmektir. "Kuşatıcı bir siyaset tarzı üretmek" derken de Ak Parti'nin farklı siyasal çizgilerden gelen kişileri bünyesinde toplaması vurgulanarak, "kimlik siyaseti" güden partilerin Türk siyasetinde tıkanıklıklara sebep olduğu iddia edilmekte ve bu tür bir siyasetten yana olunmadığını söylemektedir.

Yine de öne çıkan parti kurucularının fikirlerini şekillendirmede okul görevi gören Millî Görüş hareketinin Ak Parti'nin baskın siyasal kimliğinin oluşmasındaki etkisi belirleyicidir. Bu yapılanmanın partileri olan Milli Nizam Partisi, Milli Selamet Partisi, Refah Partisi ve son olarak da Fazilet Partisi’nin kapatılmasi, Millî Görüş dairesinde yetişen ikinci ve belki de son etkin kuşak siyasetçilerde siyasal katılımı tesis etmenin önemini birinci sıraya yükseltmiştir. Bu süreç, Fazilet Partisi'nin son dönemine rastlayan "gelenekçi”, "yenilikçi” şeklinde tanımlanan parti içi hizipleri ortaya çıkarmıştır. $\mathrm{Bu}$ gelişmeler partinin doğuşunu izah ederken tekrar ele alınacaktır.

$2 \mathrm{Bu}$ siyasal düşünce; Aydınlanma sonrasında, aklın toplumsal alanın tanziminde determinist bir yaklaşımla hareket etmesini ve toplumun kendiliğinden dönüşen yapısının müdahaleci bir yöntemle değiştirilmesini eleştirir. Thomas Hobbes, Edmund Burke, Jeremy Bentham, Friedrich August von Hayek, Robert Nozick muhafazakâr düşüncenin şekillenmesinde önemli katkıları olan düşünürlerdir. Margaret Thatcher ve Ronald Reagan muhafazakârlı̆̆ın farklı yaklaşımlarını (Yeni Muhafazakarlık) benimsemiş siyasetçilerdir. Mehmet Akif Ersoy, Ziya Gökalp, Necip Fazıl Kısakürek, Prens Sabahaddin gibi düşünürler muhafazakârlığın farklı yönlerine katkılar sunmuşlardır. Türkiye'de muhafazakâr düşüncenin gelişimini ise Erler (2007:129) şöyle özetlemektedir: “'Osmanlı'nın son dönemindeki muhafazakâr oluşum aslında Jön Türkler ve modernleşme hareketlerinin devrimci yanına karşı gelişmiştir. Kuramsal temelinde ise Ziya Gökalp'in formülize ettiği 'medeniyet-hars (kültür)' ayrımı yatar. Bu ayrım, medeniyeti 'Batı'nın bilim ve teknolojisini alma', kültürü ise 'bize ait olan ve din dâhil bütün geleneksel değerleri koruma' olarak ortaya koyar. Cumhuriyet döneminde ise muhafazakâr tepkiler ilk olarak cumhuriyete; saltanat, hilafet, tekke ve zaviyelerin kaldırllarak, kullanılan alfabe gibi var olan düzeni ve geleneksel kurumlarl sarsan ilerici ve devrimci niteliğine yöneliktir. Cumhuriyet devrimleri Batıya karşı verilen anti-emperyalist mücadelenin ardından yeni ve bağımsız bir devlet yaratma yönünde atılan adımları temsil eder. Cumhuriyet devrimleriyle nispeten daha bütünlüklü bir proje yaratılarak, medeniyet-kültür ayrımı ortadan kaldırllmaya çalışılmıştır.', 
Diğer taraftan partinin, yenilikçi hizip tarafından tek başına oluşturulduğu da söylenemez. Diğer merkez sağ partilerden kuruluş döneminde katılanlar, hükümetlerde yer alan siyasal İslam geleneğinin dışından gelenler, partiye liberal demokrat bir görünüm vermiş̧tir (Akdoğan, 2004:105).

Türk sağında (Bora, 1998) ve dolayısıyla Millî Görüş geleneğinde İslamcı görüş ile milliyetçiliği siyasal gelişimleri açısından birbirinden ayırmak oldukça güçtür. Her iki görüşün birbirine etki etmesi söz konusudur (Özbudun ve Hale, 2010). Bu durumda muhafazakâr düşüncenin pragmatist yapısı sebebiyle Ak Parti gerek kuruluşu sırasında gerekse kuruluşundan sonraki dönemde gelişmelere bağlı olarak milliyetçiliği ve İslamcıllığı zaman zaman söylem olarak kullanacaktır.

Son olarak Ak Parti'nin muhafazakâr siyaset bağlamında hangi çizgiye kendini yerleştirdiğini unutmamak gerekir. Ak Parti, içinden çıktığı Millî Görüşü ve Erbakan'ı ideolojik ve kurumsal açıdan selefi görmemektedir. Partinin lideri ve önde gelen siyasetçileri kendilerini Demokrat Parti’nin çizgisine yerleştirmektedirler. Ancak parti; özellikle eğitim alanında gerçekleştirdiği politikalar ve dindar gençlik yetiştirme söylemiyle Millî Görüş çizgisine daha yakın durmaktadır. Bunun yanında serbest piyasa ekonomisini önceleyen yaklaşımıyla, hem dünyadaki Yeni Muhafazakâr örnekleriyle benzerlik göstermekte hem de Demokrat Parti ve Anavatan Partisi çizgisini devam ettirmektedir.

\section{DOĞUS TEORILERİ VE AK PARTİ}

Duverger (1974) partilerin kökenine ilişkin iki temel doğuş kaynağından bahsetmektedir; seçimlerle parlamentoda doğan partiler ve parlamento dışından doğan partiler. Parlamento dışından doğan partiler, mecliste temsil imkânına sahip olmayan sendikalar, tarım kooperatifleri, dernekler, fikir kulüpleri gibi sosyal, kültürel ve iktisadi oluşumlardır. Ak Parti, bu ayrım dikkate alınırsa parlamento içinden doğan bir partidir. Öncelikle Millî Görüş partilerinde oluşan yenilikçi hizipleşmenin ürünü olması ve kendilerinin parlamento üyesi olmaları sebebiyle, parti bu sınıflamaya dâhil edilebilir. Ancak partilerin doğuşunda iki ayrı fakat birbirini tetikleyen aşama söz konusudur. Birincisi düşünsel, ikincisi ise fiili aşamadır.

Ak Parti'nin düşünsel doğuşunun toplumsal kaynağı parlamento dışındadır. Duverger'in parlamento dışında saydığı oluşumlar; genelde merkeziyetçi yapının karşısında konumlanan, sosyal(ist) tabanlı, aşağıdan yukarı örgütlenerek kendilerini temsil üzerinden ifade etmeye çalışan gruplardır. Ancak Ak Parti açısından, parlamento içinde doğan bu partinin kurucu kadrosu ile parlamento dışındaki toplumsal tabaka arasında organik ya da dikey bir bağ söz konusu değildir. Partinin kuruluşu ağırlıklı olarak Millî Görüş geleneğinden, merkez sağdan ve liberal çevrelerden bir araya gelen isimlerin, toplumun o günkü taleplerini anlamlandırmasının sonucudur. $\mathrm{Bu}$ durum bir bakıma katılma bunalımının (Dursun, 2008) aşılması girişimi olarak değerlendirilebilir. Özellikle 28 Şubat sürecinden sonra Millî Görüş çizgisi içinde yenilikçiler; yeni bir siyasi üslup geliştirme, demokrasi ve farklılıklara saygı söylemi etrafında birleşerek Erbakan'ın yasaklı olduğu dönemde Fazilet Partisi'nin yönetime talip oldular. Yenilikçilerden Abdulletif Şener, Abdullah Gül'ün adaylığı için; “Bu, Türkiye'de, yanlış siyaset anlayışııdan kaynaklanan siyasi boşluğa hitap eden bir olaydır"3 (Erbakan'a İlk Bayrak, 2000) diyerek geleneksel parti yönetiminin, siyasal katılmanın sağlanmasına nasıl ket vurduğunu ifade etmiştir. Bu sürecin sonunda Millî Görüş içerisindeki yenilikçi kanat, yeni kurdukları partinin ideolojik yönelimini geniş tutarak, liberal değerleri söylemlerine ekleyerek, laiklik vurgusu yaparak, muhafazakârlığı da kimliğinin gövdesine ekleyerek merkezde yer alan geniş oy tabanına ve özellikle Anavatan Partisi'nin bıraktığı siyasal mirasa sahip çıkmaya girişmiştir.

Farklı etnik, dini ve kültürel yapılardan oluşan toplumlarda, bu farklılıkları birbirinden ayıran sosyal bölünme çizgileri belirir (Özbudun, 2015). Partiler ve parti sistemleri de bu sosyal bölünme çizgilerinin yansımalarıdır (Özbudun, 2016). Eğer Türkiye'de böyle sosyal bölünme çizgileri var ise, Ak Parti bu çizgilerin birleştiği noktalar üzerinden doğmuştur. Ak Parti'nin, aldığı oy oranlarına ve bu oranların çıktığı toplumsal kesimlere bakıldığında, liberallerin, İslamcıların, muhafazakârların, milliyetçilerin varlığı sosyal bölünme çizgilerini birleştiren birçok bileşenli bir ideolojik görünüme sahip olduğu söylenebilir.

Bunlara ek olarak Kapani (2012), partilerin bölünmeleri ya da birleşmeleri sonucunda da doğabilecekleri başka bir kategoriden bahsetmektedir. Türkiye'nin de bu tarz parti oluşumları açısından zengin olduğunu belirtmektedir ${ }^{4}$. Ak Parti, bu açıdan bir bölünmenin ürünüdür. Ancak bu, yalnızca partinin fiili bölünmesi değil, ideolojik bir ayrılma ve seyrelmedir. Siyasal ideolojilerin kabuk bağlaması sonucunda ilgili partinin toplumsal

3 https://www.hurriyet.com.tr/gundem/erbakana-ilk-bayrak-39138765 (Erişim Tarihi: 10.12.2020).

4 Türkiye'deki parti bölünmeleri ve birleşmeleri, kısmen parlamenter sistemin ve seçim sisteminin etkisi, kısmen çok partili yaşamın uğradığı müdahaleler gibi sebeplere bağlanabilir. 
tabanının daralması tehlikesiyle karşı karşıya kalması söz konusudur. Ak Parti’yi kuranlar bu daralmayı fark etmişler ve ideolojik olarak beslendikleri kaynaktan ayrılarak sağdaki çeşitli kesimlere hitap eden yeni bir oluşum sürecine girmişlerdir.

\section{PARTI TIPOLOJILERİ VE AK PARTI}

Duverger'in (1974) parti tiplerine ilişkin klasik sınıflandırması kitle ve kadro partileridir. Dikkat edilecek olursa Duverger bu sınıflamayı üyelik başlığı altında yapmaktadır. Esasında bu iki parti sınıflamasının temel noktası da üyelerinin sayısı ve niteliği üzerindeki ayrımdır. Kadro partisi; demokrasinin çağdaş ilkesi genel oy yaklaşımının kabulünden önce, üyelerinin niteliği açısından Atina demokrasisinin ${ }^{5}$ 19. ve 20. Yüzyıla yansımasıdır denilebilir. Bu tipoloji; elit, varlıklı ve eğitimli bir zümrenin siyasal iktidarı elde etmek maksadıyla partileşmesidir. Atina demokrasisinden farklı olarak seçim süreçleri dışında faal olmayan bu partiler, seçim zamanında varlıklı insanların destekleriyle yarışa dâhil olurlar. Üye sayılarını artırma gibi bir kaygıları yoktur. Örgütlenme ağ gevşektir ve merkeziyetçi değildirler.

Ancak 19. Yüzyılda Sanayi ve Fransız Devriminin etkisiyle yaşanan toplumsal değişim sonucunda tacın egemenliğinden millet egemenliğine kadar varan bir süreç yaşanmıştır. Sanayileşme, kentleşme ve hızlı nüfus artışı ve sonunda genel oy ilkesinin kabulü özellikle işçi sınıfının siyasallaşması sorununu ortaya çıarmıştır. Duverger'in de kütle ${ }^{6}$ partisi tipi bu sürecin sonunda gerçekleşen partileşmenin tanımlanmasıdır. Kitle partisi belli bir toplumsal sınıfın siyasi parti üyeliği yoluyla siyasallaşmasıdır. Bu üyeler aidat ödeyerek partiyi idame ettirir ve partinin seçimlere katılmasını sağlar. Bu üyelerin endoktrine edilmesi önemlidir. Sürecin sonunda bu yapının içinden siyasal iktidarı ele geçirecek elit bir grubu çıkarmak amaçlanır (Duverger, 1974).

Duverger (1974) kadro ve kitle partileri arasında kesin bir ayrım olmadığını, bazı durumlarda bir partinin her iki özelliği taşıyabileceğini düşünmektedir. Ancak ayrımın temelinde yukarıdaki tespitlerin olduğu unutulmamalıdır. Kapani de (2012) zamanla kadro partilerinin de kitle partilerinin davranışlarını taklit ederek üye sayısını artırmaya çalıştığını belirtmektedir.

Türkiye'de ise kitle partisini, sadece üye sayısının çokluğu ve seçimlerde yüksek oy alma durumuyla oluşan bir tipoloji görme eğilimi söz konusudur. Örneğin Ak Parti’nin teşkilattan sorumlu Genel Başkan Yardımcısı Mustafa Ataş, partinin toplam üye sayısının 10 milyon civarında olduğunu belirtmiştir ${ }^{7}$. Partinin lideri Erdoğan'a göre (2004:8), Ak Parti muhafazakârlık temelinde bir kitle partisidir. Erdoğan, bu ifadeyi 2004 yılında kullanmıştır. Bundan tam on y1l sonra Genel Başkan Yardımcısı Hüseyin Çelik; "Ak Parti bir ideolojik parti değil, bir kitle partisidir. Biz prensiplerde buluşan ortak paydası muhafazakâr demokratlık olan bir siyaseti birlikte yapıyoruz", demiştir.

10 milyon üyenin hangi toplumsal kesimlere dayandığı, üyelik aidatını düzenli ödeyip ödemediği, bu üyelerin doktrine bir eğitime tabi tutulup tutulmadığı kitle partisi tanımına uyması açısından önemlidir. Ayrıca Çelik'in açıklamasına bakılacak olursa, Ak Parti üyelerinin tek ortak özelliği muhafazakâr bir yapıya sahip olmalarıdır. Eğer durum böyle ise Ak Parti için bir kitle partisidir tanımı yapılabilir. Ama Ak Parti içindeki yönetici kadronun ve üyelerinin sadece muhafazakârlardan oluşmadığ 1 ve tek ortak noktalarının muhafazakârlık olmadığı ortadadır. Bu durumda Duverger'in özgün tanımından hareket edilecek olursa Ak Parti tam olarak ne kadro ne de kitle partisi sinıflamasına uymaktadır. En önemlisi Ak Parti, belirli bir toplumsal gruba ya da sinıfa dayalı bir kitleyi, belli bir ideolojik doktrinle eğitip örgütlemediği için de kitle partisi değildir. ${ }^{10}$ Fakat merkeziyetçi ve disiplinli yapısı sebebiyle Ak Parti kitle partisi özelliği gösterir denilebilir. ${ }^{11}$ Bunun yanında siyasal açıdan seçkin bir grubun bir araya gelip partiyi kurması sebebiyle, parti kuruluş aşaması bağlamında bir kadro partisi olarak değerlendirilebilir.

5 Varlıklı erkeklerin siyasallaşabilmesi bağlamında benzerlik kurulabilir.

6 Kütle (kitle) kavramı sanayileşme çağında yaygın olarak kullanılmıştır. Kütlenin özellikle konumuz açısından önemli olan homojen, edilgen yapısı ve diğer özellikleri Gustave Le Bon (1997) gibi yazarlar tarafından ayrıntılı olarak tasvir edilmiştir. Özellikle 19. Yüzyılın tamamı ve 20. Yüzyılın başında gerçekleşen ulusal ve uluslararası olayları tahlil etmede kitleyi ve kitle psikolojisini anlamak önemlidir.

7 http://www.akparti.org.tr/site/haberler/ak-partinin-uye-sayisi-10-milyona-yaklasmis-vaziyette/83323\#1 (Erişim Tarihi: 03.08.2020).

8 Sonuç olarak bu anlatımlara bakılırsa, kitle ile toplum kavramları birbiriyle karıştırılmaktadır. Kitle homojen bir nitelik arz ederken, toplum ise konumuz bağlamında siyasal açıdan farklı hassasiyetleri olan toplulukların, kitlelerin bir araya gelmesiyle oluşur.

9 https://www.akparti.org.tr/site/haberler/ak-parti-bir-kitle-partisidir/64162\#1 (Erişim Tarihi: 10.08.2020).

10 Duverger'in bu tanımlamalarının kitle iletişim araçlarının günümüz ölçüsünde yaygınlaşmadığı ve iki kutuplu sistemde siyasal ideolojilerin çatıştı̆̆ bir ortamda geliştiğini unutmamak gerekir.

11 Bu bağlamda Türkiye'deki hemen hemen bütün partiler aynı özelliği taşımaktadır. 
Sonuçta eğer bir parti kitle ve kadro partisi özelliklerini gösteriyorsa yeni sınıflamalara ihtiyaç vardır. Duverger, daha sonraki çalışmalarında bu ayrımın dışında "ara parti" adında üçüncü bir kategoriye yer verir (Kapani, 2012). Bunlar da "dolaylı partiler" ve "azgelişmiş ülkelerin partileri” olmak üzere ikiye ayrılır. Ancak bu tipolojiler Türkiye'deki partileri sınıflandırmada uygun değildir.

Bir başka önemli parti tipolojisi ise Neuman'ın (1956) "bireysel temsil" ve "sosyal bütünleşme partileri”" ayrımıdır. Bireysel temsil partileri çoğunlukla seçim dönemlerinde faaliyetini yoğunlaştırır ve temel amacı aday göstermektir. Siyasal katılma sınırlı ve dar bir boyutta gerçekleşir. Aday gösterilen kişiler seçildikten sonra tam bir serbestlik içinde hareket eder. Üyelerin aktif katılımı ve kontrolü söz konusu değildir. Bu parti tipolojisi Amerikan siyasal sisteminde yeşeren Demokrat ve Cumhuriyetçi partilerin örgütlenmesine örnektir (Kapani, 2012). Sosyal bütünleşme partileri ise üyeleri ideolojik ve örgütsel olarak bir araya getiren, onların sosyal hayatlarını ve partiyle ilişkilerini düzenlemeye çalışan oluşumlardır. Bu tipoloji de "demokratik bütünleşme" ve "toptan bütünleşme" partileri adı altında ikiye ayrılır. Adından da anlaşılacağı üzere birincisi daha açık bir nitelikle farklı sosyal, kentli sınıfları bütünleştirmeyi arzularken, ikincisi ise faşist ve komünist rejimlerde gözlemlendiği üzere totaliter bir bütünleşmeyi hedefler. Ak Parti, bu sınıflamaya göre demokratik nitelikli bir bütünleşme partisi olabilir. Siyasal İslam eksenli siyaset yapan politikacıların ve seçmenlerin muhafazakâr bir siyaset tarzı etrafında bütünleşmesi söz konusudur. Bunun sonucunda katılma krizi aşılmış, daha sonrasında yaşanması muhtemel siyasal sistem tıkanıklıklarının önüne geçilmiştir. İdeolojik yumuşama farklı nitelikteki seçmenlerin temsilini sağlamış ve böylece siyasal bütünleşme gerçekleşmiştir.

Özbudun'a göre (2003:69); “Türkiye'deki partiler genelde kitle partisi özelliklerini gösterememişlerdir, ancak daha ziyade bunlar kadro, herkesi kucaklayan parti ve kartel partilerinin özelliklerini birleştirmişlerdir”. Kadro partisi modelinden herkesi yakala ya da kartel partisi modeline geçmeleri, kitle partisi özelliklerini atlamaları, Türk siyasi partilerinin ortak yönleridir (Özbudun, 2003:83).

Özbudun, 2007 yılında yaptığı bir değerlendirmede bu görüşünü yenilemektedir. Bu kapsamda; “AK Parti elbette bir sinıf partisi değildir. Aksine, kırsal ve kentsel bölgelerden, yükselen muhafazakâr burjuvazi ile büyük kentlerin yoksul kesimlerinden oy alan tipik bir 'herkesi kucaklayan (catch-all)' partidir"'12, demiştir. Kalaycıŏglu (2008:299)'na göre de; Ak Parti'nin Türk milliyetçiliği, İslamcılık, liberalizm ve sosyal demokrasi gibi büyük ideolojileri kullanarak gerçek konumlarını açığa çıkarmak yerine, herkesi yakala partilerinin yaptı̆̆ gibi seçmenlerin kafasını karıştırmaktadır. Hepsini yakala partilerinde olduğu gibi Ak Parti seçmeni de ideolojik değil pragmatik ve hatta ekonomik çıkarları sebebiyle partiyi desteklemektedir.

Bu durumda, "hepsini yakala" partisi tipolojisini tanımlamak gerekmektedir. Herkesi yakala (Catch all) parti tipi Kirchheimer (1966) tarafından geliştirilmiştir. Bu parti tipolojisinde kitlesel bütünleşme partilerinin, oy potansiyelini artırıp hızlı bir şekilde sonuç almak için ideolojik açıdan yumuşaması ve örgütsel yapısında da gevşemesi söz konusudur. Bu tanımlama Ak Parti’nin doğuş sürecini izah etmede yeterli sayılabilir. Bilindiği üzere Ergun Özbudun, Refah Partisi'ni bir kitle partisi olarak tanımlamaktadır. Refah Partisi, Millî Görüş çizgisinin iktidar olmuş en etkin partisiydi. Ak Parti'deki yenilikçiler de bu çizgi içindeki İslamcı ideolojik bağl1lı̆̆ eleştirerek ayrılma sürecine girmişlerdi. Sonrasında ise radikal İslamcı çizgiden muhafazakâr demokrat kimliğe bürünen, liberal piyasa odaklı, pragmatist milliyetçi bir parti ortaya çıkmıştır.

Herkesi yakala tipi partiler İkinci Dünya Savaşı sonrasında yaşanan gelişmelerin ürünüdürler. İdeolojik yayılmadan ziyade seçmenlerin sayısını (üyelerin değil) artırmak temel hedefleridir. Bir toplumsal sınıftan değil, birçok toplumsal tabakadan oy almayı hedeflemektedir. Bu amaçla iletişim tekniklerini ve kitle medyasında uzmanlaşmış kişileri kullanırlar (Sayarı, 2015:132). Ak Parti'nin de bu parti sınıflamasına dâhil edilmesinde kanıt olarak sunulabilecek tarihsel gelişmeler söz konusudur. Bunlardan birincisi solun önemli isimlerinden Ertuğrul Günay'ın partiye katılması ve kültür bakanı olmasıdır. Bunun yanında Alevi açılımı altında sol partilere oy veren toplumsal sınıfların kazanılmasına yönelik girişimlerde bulunulmuştur. Diğer bir kanıt ise sağdaki diğer partilerin liderlerinin Ak Parti saflarına katılmasıdır. Bunlardan en önemlileri Süleyman Soylu ve Numan Kurtulmuş olarak gösterilebilir. Sağdaki oy potansiyelinin büyüklüğü sebebiyle Ak Parti bu kulvarda parçalanmış küçük partileri ve liderleri yanına çekerek oy pastasını genişletmeye çalışmaktadır. Bu durumda merkez bir ideolojinin parti kimliğinde kemikleşmesi beklenemez. Seçim başarıları ve ardından gelen bu katılımlar için kartopu modeli tabiri kullanılması mümkün olabilir. Ak Parti’nin ekonomik göstergelerinde iyileşmesi paralelinde kazandığı seçimler sonucunda, sağdaki seçmende ve siyasetçilerde ideolojik yumuşama gerçekleşmiş ve yukarıda adı geçen siyasetçiler sağda çekim gücünü artıran Ak Parti’ye katılmışlardır.

12 http://www.dunyabulteni.net/?aType=yazarHaber\&ArticleID=1869 (Erişim Tarihi: 10.08.2020). 
Ayrıca seçimlerde $\% 7$ oy oranı alan partilerin hazine yardımı almaları sebebiyle, bu oranı geçen partiler de kartel partisi (Katz ve Mair, 1995) tipolojisine uymaktadırlar. Özbudun (2003:82-83) kartel partilerinin özeliklerini şöyle sıralamaktadır; siyasetin ana gayesi, "meslek olarak siyasettir, parti faaliyetleri sermaye odaklıdır, partiler devlet yardımlarına bağımlıdırlar ve bunlara bağlı olarak partiler devlet aygıtına entegre olarak varlıklarını sürdürürler".

Bir diğer parti tipolojisi ise Panebianco'nun (1988) "seçimlere dönük profesyonel parti” tanımlamasıdır. Bu partiler, Duverger'in kitle partisindeki gibi üyelere yönelik ideolojik kimlik oluşturma gayesi gütmezler. Zayıf örgütsel yapıya sahiptirler, toplanan bağışlar ve devlet yardımlarıyla seçim kazanmaya odaklanırlar ve partinin sevk ve idaresinde profesyoneller söz sahibidir. Bu bakımdan Ak Parti'nin aynı zamanda profesyonel parti özeliklerine de kısmen sahip olduğu söylenebilir. Gerçekten de partinin politikalarını hem ideolojik (Yalçın Akdoğan) hem iktisadi anlamda (Ali Babacan, Mehmet Şimşek) inşa eden ve yönlendiren profesyoneller olmuştur. Bunun yanında seçimler için çağdaş reklam teknikleri ve popüler reklamcılarla çalışılmıştır. Ancak bu bağlamda günümüz partileri de benzer yöntemleri uygulamaktadırlar. Örneğin Cumhuriyet Halk Partisi de belli alanlarda profesyonel kişileri parti içine almakta ve partinin ideolojisiyle şekillenen geleneksel söylemin yanında, bu kişilerin oluşturduğu söylemler üzerinden de seçmeni ikna etme girişiminde bulunmaktadır. Bu bağlamda Selin Sayek Böke'nin CHP'nin ekonomiye ilişkin muhalefet söylemini üstlenmesi örnek olarak verilebilir. Ancak Ak Parti bu stratejiyi kurulduğu günden beri uygulamaktadır.

\section{PARTI SISTEMLERİ VE AK PARTI}

Parti sistemleri; temel olarak toplumdaki siyasal akımların yansımasıyla oluşur ve siyasal sisteme etki eden partiler hesaba katılarak pratik olması açısından sayısal olarak tanımlanabilir. Bu bağlamda tek parti, iki parti ve çok partili sistemlerden bahsetmek mümkünüdür (Sartori, 2005). Ancak parti sistemleri açısından Türkiye'deki durumu sayı noktasında tarif etmek oldukça güçtür. Nispi temsil yöntemi, \%10 ülke barajı, toplumdaki ideolojik bölünmelerin çeşitli ve sayıca fazla olması bunun başlıca sebeplerindendir. Özbudun'un (2016) belirttiği üzere partiler, toplumlardaki bölünme çizgilerinin yansımalarıdır. Toplum tek bir sorun çizgisinde bölünmüşse iki partili bir sistemin, daha fazla sorun ekseninde bölünmüşse sayıca fazla partili bir sistemin olması beklenir. Fakat genel olarak Türkiye'de parti sistemleri analizi, sosyolojik temellendirme açısından, yaygın olarak merkez-çevre ayrışması üzerinden yapılmaktadır.

Kapani’ye göre (2012) Türkiye'de öteden beri devam eden iki partili eğilim, nispi temsil sisteminin kabulünden sonra da devam etmiştir. Burada merkez ve çevre bağlamında iki bölünme çizgisi olduğu ve çevreyi Ak Parti'nin temsil ettiği düşünülmektedir. Bu bağlamda Ak Parti; "karsal nüfusun önemli bir kesimini, şehirli esnaf ve zanaatkârlarl, beden iş̧̧ilerini, şehirlerin düşük gelirli kesimlerini, Kürtlerin önemli bir bölümünü ve hızla yükselen Anadolu burjuvazisini" (Özbudun, 2016:48) temsil etmektedir. Özbudun (2016) bu sosyal çeşitliliğe sahip kesimlerin ortak noktasının laik ve vesayetçi merkez tarafından dışlanmaları olduğunu belirtir. Ak Parti, bu sosyal bölünmüşlüğün ortak noktasını da dikkate alarak herkesi yakala partisi tekniklerini de kullanmakta, sağda geniş oylar almayı ve siyasal bütünleşmeyi sağlamaktadır. Bu sosyal gerçeklik hem parti sisteminin şekillenmesini hem de bunun tarif edilmesini sağlayacaktır. Bu noktada Ak Parti dönemiyle birlikte sağdaki oyların bu partiye doğru akması ve ülke barajının etkisi, iki partinin de güç açısından birbirine yakın olduğu ve iktidarın el değiştirdiği iki partili sistemle, Türkiye örneğini birbirinden uzaklaştırmaktadır.

Bunun yanında oynaklık ve parçalanmışlık kavramları (Özbudun, 2003:71) parti sistemlerini tanımlarken kullanılan teknik ifadelerdir. Oynaklık, bir partinin bir seçimden diğerine aldığı oy oranındaki dalgalanmayı ifade ederken; parçalanmışlık, seçim sonucunda parlamentoda yer alan partilerin sayıca fazlalığını ifade eder. Ak Parti öncesinde hem oynaklığın hem de parçalanmışlığın sıkça gerçekleştiği parti sistemleri tezahür etmiştir. Ayrıca siyasal rejimlerin farklı ve özgün yapısından dolayı parti sistemlerine ilişkin sınıflandırmanın yanlışlanabilir olduğu düşünülmektedir (Yanık, 2003:271). Bu bağlamda Ak Parti ile özellikle sağdaki parçalanmışlık ve oynaklık ortadan kalksa da sistem ne belirgin iki partiye ne tam anlamıyla hâkim tek partiye dönüşmüştür. Burada sistemin ayrıştığ nokta, Ak Parti'nin küçük bir oy kaybında, parlamentoya girecek olan diğer partilerin koalisyon kurması durumudur. $\mathrm{Bu}$ durumda, 2015 Haziran seçimi sonucunda oluşan parti sistemini tahlil etmede Sartori'nin (Sartori, 2005:107-110) yaklaşımı yol göstericidir. Bu yaklaşım, küçük oy oranına sahip partinin koalisyona katılma ve korkutma potansiyeline bakılır. Bu bağlamda Ak Parti'nin tek başına iktidarı kuramamış olması ve diğer partilerle koalisyon kurma ihtimaliyle karşı karşıya kalması Sartori'nin tahlilini anımsatır mahiyettedir. Ancak yenilenen seçimler sonrasında Ak Parti tekrar hâkim parti pozisyonuna gelmiştir. 
Cumhuriyet Halk Partisi'nin de Kemal Kılıçdaroğlu ile herkesi yakala partisi özellikleri taşımaya başlaması, türban açılımı kapsamında dışlayıcı laiklik konumunu gevşetmesi, sosyal devlet söylemini güçlendirerek Ak Parti'nin yükseliş dönemindeki yaklaşımını benimsemesi merkez-çevre çatışmasındaki din tabanlı odağın kaymasına sebep olmuştur. Bu gelişmeye Halkların Demokrasi Partisi'nin de sol söylemlerle katılması, “çözüm süreci"nden faydalanarak söylemini sertleştirmesi ve Cumhuriyet Halk Partisi'nin bir kısım seçmeniyle zımni bir mutabakata girmesi, 2015 Haziran seçimlerindeki sonucu doğurmuş ve Ak Parti'nin karmaşık tek partili sistemde bir kategori olan hâkim parti pozisyonunu tehlikeye düşürmüştür. ${ }^{13}$ Bu durumun gerçekleşmesinde merkez-çevre çatışmasının Özbudun açısından belirleyici noktası olan kültürel ayrışmanın yumuşaması ve Ak Parti’nin zayıf olduğu ayrışma alanlarının (milliyetçilik) ön plana çıkması gerekçe olarak gösterilebilir.

\section{SIYYASI PARTILERDE KURUMSALLAŞMA VE AK PARTİ}

Huntington'a göre (1966:65) siyasal örgütlerin gücü, örgüt ağının toplumsal tabana yayılma ölçüsüne ve örgütün kurumsallaşma düzeyine bağlıdır. Kurumsallaşma ise; "bir siyasal sistemin kurumlaşma düzeyi, o sistemdeki örgüt ve usullerin uyarlanabilirliği (adaptability), karmaş̧klı̆̆l (complexity), özerkliği (autonomy) ve tutarlı̆̆ (coherence)" ile ölçülebilir.

Uyurlanabilirlik ile bükülmezlik arasında ters ilişki söz konusudur. Örgüt ne kadar eski ve çevrenin baskılarına ne kadar maruz kalmışsa o oranda uyarlanabilir olmuştur. Bunun anlamı, değişen şartlarda çevreden gelen değişik baskılara karşı örgütün kendini adapte edebilmesidir. Bu bağlamda Ak Parti, kuruluşundan bugüne kadar geçen süreçte gerek hukuki gerek ekonomik gerekse siyasal içerikli birçok kriz atlatmıştır. Kapatma davası, partiden ayrılanların partiyi kötüleyen beyanatları, Gezi Parkı protestoları, Cumhurbaşkanlığı seçimleri sırasında gerçekleşen lider değişikliği bunlardan sadece bazılarıdır. Bu bağlamda gerçekleşen krizlere ve baskılara direnebildiğinden partinin uyarlanabilirliği yüksektir denilebilir.

Huntington'a göre (1966:65-68) uyarlanabilirliğin ölçütleri ise kronolojik ve kuşaksal yaş ile fonksiyonelliktir. Kronolojik yaş örgütün ya da usulün ömrüne tekabül eder ve ne kadar uzunsa, örgütün ya da usulün o oranda kurumsal olduğunu gösterir. Kuşaksal yaş ise örgütün kurucular tarafından m1, yoksa ondan sonra gelen kuşaklar tarafından $\mathrm{m}$ yönetildiğini dikkate alır. Bu durumda yönetici kuş̧akların değişmesi kurumsal ömrü uzatır. Ak Parti liderliğinde kuşaksa ${ }^{14}$ bir değişim olmamıştır. Sadece aynı kuşak içinde liderler arasında bir değişim söz konusudur. Bu bakımdan kuşaksal bir değişime nazaran daha az tehditkâr bir değişim süreci yaşanmıştır.

Üçüncüsü ise örgüte fonksiyonel açıdan ihtiyaç kalmaması tehlikesidir. Bu tehlikeye karşı kurum kendisini fonksiyonel olarak uyarlayabiliyorsa kurumsallaşıyor demektir. Ak Parti fonksiyonel yaşını çeşitlendirme adına uzak geleceğe yönelik hedefler ve söylemler geliştirmektedir. Türkiye'nin en azından ekonomik açıdan belli bir yere getirilmesindeki herkesçe kabul edilen fonksiyonu seçmende partinin misyonunu tamamladığı algısını oluşturabilir. Bu düşünce hali Gezi Olayları ve 17-25 Aralık süreçleriyle de birleşince seçmenin eğilimi diğer partilere kayabilirdi. Buna karşılık parti, "Yeni Türkiye" söylemini 2023 ve 2071 hedeflerini, tamamlanması yıllar alacak olan devasa projeleri üretmiş ve bu hedeflerin ve projelerin gerçekleşmesiyle kendi fonksiyonel varlığını seçmenin gözünde eşleştirmiştir. Bu yöntemle parti, kendi fonksiyonel rolünü gelecek ile bağdaştırarak bugünkü seçmenin tercihini yönlendirmeyi amaçlamaktadır. Bu bağlamda parti fonksiyonel yaşını uzatmaya çalışmaktadır.

"Karmaşıklık, hem örgütsel alt-birimlerin (subunits) hiyerarşik ve fonksiyonel bakımdan çoğalması, hem de çeşitli alt-birim tiplerinin farklılaşması anlamına gelir" (Huntington, 1966:71). Karmaşıklık totaliter örgütlenmenin aksine, gücün, sorumluluğun ve iktidarın paylaşıldığı bir kurumu ve sistemi öngörür. Ak Parti'de Gençlik Kolları ve Kadın Kolları partinin aktif olarak çalışan alt birimleri arasındadır. Ancak bu birimlerin merkezin ve liderin politikalarını şekillendirmede, karar alma mekanizmalarına katılmada etkin oldukları ve partinin karmaşılık bağlamında kurumsallaşmasına katkı sunduklarını söylemek zordur. Bu noktada Türk siyasi partilerinde yaygın olarak görülen oligarşinin tunç kanununun (Michels, 1915:377-392) Ak Parti için de geçerli olduğu iddia edilebilir. Belirleyici olan bütün politikalar ve kararlar karmaşık bir ağın istişaresinden değil, nihayetinde liderin iradesinden doğmaktadır.

13 Özbudun'a göre (2016) Türkiye'de genel olarak iki partili sistemden çok partili sisteme doğru bir değişim yaşanmıştır. Özbudun, Ak Parti'nin üçüncü seçim zaferi (2011) ile birlikte hâkim parti sistemine doğru bir değişim olduğunu vurgulamaktadır. Ancak hâkim parti sitemine doğru yaşanan bu trendin 2015 'te gerçekleşen kırılmayla sekteye uğradığını not etmek gerekir. Ak Parti kısa süre içinde yenilenen seçimlerle tekrar hâkim parti konumuna yükselmiştir.

14 Kuşaklar arası yetişme ve bakış açısı farklılıkları olduğundan değişim ve süreklilik örgütün kurumsallaşması açısından daha risklidir. 
Huntington'a göre (1966:73) bir diğer kurumsallaşma ölçütü özerkliktir. Özerklik açısından siyasal kurumlaşma, "belli sosyal grupların menfaatlerini ifade araçlarından ibaret olmayan siyasal örgüt ve usullerin gelişmesi demektir". Bu açıdan Ak Parti'nin kurulması sürecinde ideolojik olarak yumuşamaya gitmesi, Millî Görüş’ün "dar" çizgisinden çıkarak muhafazakâr kimliği benimsemesi, liberal, milliyetçi söylemleri kullanması partinin özerkliğini kuvvetlendirdiği söylenebilir. Belli bir ideolojik ve sosyal çevreye hitap etmesi durumunda, bu sosyal ve ideolojik çevrenin talep ve çıkarlarına göre hareket etmesi söz konusu olacak, parti de belli bir ölçüde "kurumsallaşamayacaktı". Özerkliği güçlendiren bir diğer önemli unsur ise kazanılan seçimlerdir. Ak Parti seçim kazandıkça, kendi yaklaşımını ve söylemini daha rahat ifade etmeye başlamış, kamuoyunda gerçekleşen tartışmaların gündemini belirler bir konuma yükselmiştir.

Kurumsallaşmanın bir diğer ölçüttü ise tutarlılıktır. Huntington'a (1966:75) göre; “bir örgütün birlik ve tutarlı̆̆l ne kadar kuvvetli ise, kurumlaşma düzeyi de o kadar yüksektir. Örgüt, birlikten ne derece yoksunsa, o derece az kurumlaşmıştır". Türkiye'de sağ partilerin özellikle merkeziyetçi yapıları, partinin birliği noktasında da olumlu katkı sunar. Ancak bu durum, parti içindeki görüş ayrılıklarının demokratik yollarla dışa vurulmasını engelleme ya da bu düşünceleri bastırma bağlamında bir birlik görüntüsü verir. Aynı durum Ak parti için de geçerlidir. Tutarlılık ise hepsini yakala tipi pragmatist bir parti için uyulması oldukça zor bir ölçüttür. Siyasal bir örgütte ideolojik çeşitliliğin yaşanması tutarlılığı güçleştiren bir olgudur.

Türkiye'de partilerin ömürlerine ve örgütsel yapılarına bakıldığında bazı partilerin farklı ölçütler çerçevesinde nispeten daha kurumsal bir yapıya sahip olduğu düşünülebilir. Gerek sağda gerekse solda yer alıp merkeze doğru açılımda bulunan partilerin ${ }^{15}$ (hepsini yakala özelliği gösteren) kurumsallaşamadıkları söylenebilir. Bu sebeple partilerin kurumsallaşmasındaki hukuki, sosyolojik ve siyasal engelleri karşılaştırmalı olarak ele almak Ak Parti'nin de kurumsallaşma potansiyeline ilişkin ipucu verecektir.

$\mathrm{Bu}$ bağlamda Ak Parti sağ siyasetin çeşitli formlarını bünyesinde barındıran, muhafazakâr siyasal davranışı kendisine omurga edinen siyasal bir örgüttür. Ak Parti'nin siyasal örgütlenmesi, örgüt içi davranış sergileme şekli Türkiye'deki diğer sağ partilerden farklılık göstermez. Partinin 30 Eylül 2012'de yayımlanan 2023 vizyon belgesinde (2023 Siyasi Vizyon) siyasi partilere ilişkin şu ifadeler yer almaktadır;

"Siyasi partiler demokratik hayatın vazgeçilmez unsurlarıdır. Fakat ülkemizde Anayasa ve yasalar; partilerin tüzükleri, teşkilatlanmaları, programları ve faaliyetleri alanında bir dizi yasaklar ve sinırlayıcı kurallar içermektedir. Adeta siyasi partiler birer kamu kurumu, partilerin tüzük ve programları birer kamu yönetmeliği, faaliyetleri ise bir devlet faaliyeti biçiminde tanımlanmıştır. Tek tipçi anlayış siyaset alanına da hâkim kılınmıştır. Bu, siyasi partilerin bir halk kurumu, sivil toplum örgütü olma özelliğini ortadan kaldıran bir yaklaşımdır. Ayrıca, siyasetçilerin milletimizin sorumluluğunu layıkıyla taşıyamayacă̆ına inanan, bu nedenle siyasete ve siyasetçiye güvenmeyen, siyaseti ve siyasetçiyi itibarsızlaştırmak isteyen vesayetçi anlayışın bir ürünüdür."

Ak Partinin, siyasi partilere ilişkin bu mevzuatı demokratikleştirmek konusunda çekimser davrandığ 1 söylenebilir. Bahsi geçen değişiklikler gerçekleştiğinde Türkiye'deki partilerin merkeziyetçi ve tek tipçi yapılanması sarsilacak ve muhtemelen Ak Parti de bundan etkilenecektir. Bu sebeple Türkiye'de mevcut siyasal sistemde ve Türk yönetim geleneği içerisinde iktidar olmayı tek başına başarabilmiş bir siyasi partinin, siyasi partilere ilişkin demokratik yasal düzenlemeler yaparak kurumsallaşmanın önündeki hukuki engelleri kaldırması düşük bir ihtimaldir. Bu durumda Ak Parti'nin tüzel kişiliği değil, liderinin otoritesi kurumsallaşmaktadır.

Siyasi partiler kanununun dikey örgütlenmeyi öngörmesi ${ }^{16}$ yerel örgütlerin merkezi yönetimi etkileme gücünün sınırlı oluşu partilerin demokratik bir yapıya kavuşması ve dolayısıyla kurumsallaşabilmesinin önündeki başlıca engeller olarak gösterilmektedir (Özbudun, 2003:79). Kapani’ye göre (2012:181) 1982 tarihli Siyasi Partiler Kanunu, "aşırı müdahaleci bir yaklaşımla partileri devletin gözetim ve denetiminde 'uygun adım' yürüyen 'disiplinli' kuruluşlar haline getirmiştir". Demokratikleşmenin ve kurumsallaşmanın gerçekleşmesini engelleyen bu sorunlar sistem boyutunda ele alınabilir. Ancak Cumhuriyet Halk Partisi'nin ve nispeten kisa süreli de olsa Milliyetçi Hareket Partisi’nin kurumsallaşan kimliği Türkiye özelinde, mevcut yasaya rağmen, bir genelleme yapma ihtimalini ortadan kaldırmaktadır. ${ }^{17} \mathrm{Bu}$ durumda Türkiye'de siyasallaşmanın iki alanı arasında

15 Cumhuriyet Halk Partisi, tarihsel fonksiyonu ve tabanının partiye sadık ideolojik yönelimi (Aydınlanmacı Kemalist bakış) sebebiyle istisnadir.

16 Kanımızca liberal demokratik sisteme sahip bir ülkede kanun üzerinden siyasal örgütlenmelerin tarif edilmesi bir zaruret değildir. Esas olan, kurumlar üzerinden kanunlarla siyasal hakların tanımlanması değil, birey üzerinden siyasal hakların tanımlanması ve bireylerin bu haklarını kullanmasına imkân sağlanmasıdır. Böyle bir hareket alanı yatay örgütlenmenin önünü açacaktır.

17 Buradaki değerlendirmede Kürt kökenli siyasal davranış analiz dışında tutulmaktadır. Onlar için paradoksal olan durum, ırkçı bir söylem üzerinden mi, yoksa sol bir söylem üzerinden mi siyasallaşacaklarıdır. Birinci söylem partinin marjinalleşmesine (bu 
ayrım yapmak gerekecektir. Bunlardan birincisi merkeziyetçi, devletçi, Batıcı geleneğe sahip Cumhuriyet Halk Partisi ${ }^{18}$ ve ikincisi ise daha çok liberal, İslamcı ve muhafazakâr gruba yerleştirilen sağ partilerdir.

Cumhuriyet Halk Partisi ve bu partiye oy veren toplumsal tabaka ile "sağ" toplumsal tabakanın siyasal düşünce ve davranışının arkasındaki örüntü, partilerin kurumsallaşmasını doğrudan etkilemektedir. Bilindiği üzere Bülent Ecevit'in Demokratik Sol Parti'deki, Necmettin Erbakan'ın Millî Görüş partilerindeki, Süleyman Demirel'in Adalet Partisi ile Doğru Yol Partisi'ndeki ve Alparslan Türkeş'in Milliyetçi Hareket Partisi'ndeki uzun süreli liderlikleri ve yönetimleri ayrı ayrı değerlendirilmesi gereken örneklerdir. Bu partilerdeki liderlerin efsanevi kurucu figür olmaları, Türk yönetim geleneğinin etkisiyle de pekişir. Bu sebeple liderin ömrüyle partinin etkin siyasal aktör olarak varlığını sürdürmesi doğru orantılıdır. Buradaki istisna Milliyetçi Hareket Partisi'dir.

Milliyetçi Hareket Partisi'nin siyasal ideolojisi Cumhuriyet Halk Partisi'nde olduğu gibi kurumsallaşmaya müsaittir. Parti, toplumsal düzeni ve toplumsal "gelişmeyi" tarif ederken "dünyevi tecrübeyle" belirlenmiş ilkeler üzerinden hareket etmektedir. Lider, partinin kurumsal kimliğini oluşturan bu ilkeler üzerine vurgu yaparak meşruiyetini sağlamaya çalışır. Bu gelenekte kurumun siyasal kimliği oluşurken "dünyevi”, insani ve Batılı anlamda evrensel bir kodlama gerekliliği doğar. Bu açıdan bakıldığında Özbudun'un (2003:78) işaret ettiği üzere Cumhuriyet Halk Partisi kuruluş ilkelerini benimseyen toplumsal zümrenin sadık partisi olarak kalmıştır. Milliyetçi Hareket Partisi ise sağ tabanda örgütlenen bir siyasal oluşum olmasına rağmen, devletin kurulu şeklinin devamını arzulaması bağlamında Cumhuriyet Halk Partisi ile benzeşmiştir. Ayrıca kendi siyasal kimliğinde öne çıkan milliyetçilik vurgusuyla sağın "İslamcı" seçmen kitlesinden kısmen uzaklaşmıştır.

Sağ partilerde ve dolayısıyla Ak Parti'de de partiye ve parti liderine olan bağlilık; ilkeler ve kurumsal yapılar üzerinden değil, gelenek ve liderin uygulamaları üzerinden şekillenir. Bu gelenek; liderin önceki siyasal figürlerden damıttığı söylemler ve üzerine kendi eylemlerinden kattığı uygulamalardır. Bu sebeple liderin varlığı, eylemleri, öngörüsü ve gücü partinin kurumsallaşmasını doğrudan etkilemektedir. Farklı bir kuşakla gelen yeni bir lider, yeni bir parti kurmakta ve kendi varlığını, düşüncelerini ve eylemlerini kurumsallaştırmaktadır. Kemikleşmiş bir siyasal ideolojiye ve kimliğe sahip olmayan bu partiler, pragmatist bir yaklaşımla farklı dönemlerde çeşitli siyasal ideolojileri ve söylemleri benimsediğinden belirli bir parti üzerinden kurumsallaşma gerçekleşmemektedir.

$\mathrm{Bu}$ durumda partinin kurumsallaşmasına ilişkin Huntington'un kriterlerinin ötesinde daha makro bir değerlendirme yapmak gerekirse, toplumun yöneten ve yönetilen şeklinde iki sınıfa ayrıldığı (Mosca, 1939:50) sosyolojik önermenin Ak Parti için de geçerli olduğu düşünülebilir. Parti içinde siyasal otoriteyi sağlayan lider etrafındaki belirli bir elit grup (Pareto, 1968:36) belirli süreliğine partinin kalanını ve iktidarda kaldığı sürece de toplumu idare etmektedir.

\section{SONUÇ}

Ak Parti'nin tipolojik özelliklerini farklı kıstasları dikkate alarak tanımlamak gerekmektedir. Bunun temel sebebi Türkiye'de seçmen kitlesinin sosyolojik çeşitliliği ve ideolojik açıdan asimetrik geçişkenliği ${ }^{19}$ ve buna bağlı olarak da partinin bu seçmen kitlesini ikna etmek adına geliştirdiği politikaların süreç içinde farklılık göstermesidir. Bunun yanında seçim sistemi ve siyasi partiler kanunu gibi etkenler de söz konusudur.

Ak Parti, Millî Görüş geleneğinin tabanını oluşturan belirli bir kitlenin katılma bunalımını aşma maksadıyla, kurucu kadrosunun niteliği bağlamında parlamento içinden bölünme sonucunda doğmuş̧ur. Buna ek olarak Ak Parti de diğer sağ partiler gibi lider merkezli yapılanmış bir örgüttür. Katılma bunalımının aşılması bağlamında toplumsal beklentilerin karşılanması açısından partinin doğuşunu tetikleyen dinamikler parlamento dışında gerçekleşmiştir. Buna kanıt olarak partinin kuruluşundan çok kısa bir süre sonra \%34 oy oranına ulaşması gösterilebilir.

Ak Parti, kurucuların ve bugüne kadar partiye yön veren "elitlerin" niteliklerine bakıldığında kadro partisi özelliğine kısmen sahiptir. Diğer taraftan partinin; katılma bunalımını aşma sürecinde etkileşimde bulunduğu

durumda sağ, muhafazakâr Kürt kökenli oyları da kaybedecektir), ikinci söylem ise bu günkü Cumhuriyet Halk Partisi söylemiyle benzeşerek ırkçı temele dayanan tabanını kaybetmesine sebep olacaktır. Bu sebeple gerek siyasal aktörlerin gerekse seçmenlerin davranışlarının tahlil edilebilmesi için 2000'li yıllarla başlayan özgür, çoğulcu, siyasal ortamın belirli bir süre daha yaşanması gerekmektedir.

18 Kemal Kılıçdaroğlu dönemiyle birlikte Cumhuriyet Halk Partisi'nde sol siyaset ve söylem etkin olmaya başlamıştır.

19 Kürt bir seçmenin hem dindar hem de Kürt milliyetçisi olması durumunda aynı anda farklı partilere eğilim gösterebilme ihtimalini ifade etmektedir. 
tabanın homojen yapısı dikkate alındığında bir kitleye meyyal olduğu ve merkeziyetçi yapısı üzerinden örgütün disipline edilmesi sebebiyle kitle partisinin bazı özelliklerini taşıdığı söylenebilir. Ancak Ak Parti geleneksel anlamda kitle partisi değildir. Parti yöneticilerinin kendilerini kitle partisi olarak tanımlamasının görünür sebebi parti seçmeninin büyüklügüne yapılan vurgudur. Diğer taraftan Ak Parti’nin kitle partisi olarak tanımlanmasında, sanayileşme sürecinde kitle partilerinin ezilenlerin haklarını temsil etmesiyle kitle partisine yönelik oluşan "örtük sempati” ile Türkiye sosyolojisi açısından çevreyi temsil ettiği düşünülen Ak Parti seçmenini konum ve işlev açısından toplumun gözünde eşleştirmek olabilir. Partide işçi sınıfının siyasallaşması sürecindekine benzer homojen bir kitleye yönelik doktiner bir üye eğitimi söz konusu değildir. Kitle partilerinin karakteristiğinde yer alan katı ideolojik örgütlenme partinin programında yer almamaktadır. Aksine partinin muhafazakâr demokrat olarak tanımlanmasıyla ideolojik açıdan geçişkenliğe müsait, seyreltilmiş ve hibrit bir ideoloji benimsenmiştir. Ak Parti'nin tabanında Millî Görüş döneminden miras kalan dindar kitle ile dini hassasiyetleri olmakla birlikte ideolojik açıdan da çeşitlilik gösteren ve toplumun çoğunluğunu oluşturan daha geniş heterojen bir kitle, “muhafazakâr demokrat” kimlikli Ak Parti'nin kurulmasıyla Neumann'ın tarifine uygun olarak sosyal ve siyasal anlamda bütünleşmiştir. Bu bütünleşmede geniş toplumsal tabanın heterojen karakterine uygun bir şekilde Ak Parti'nin de en azından ideolojik anlamda yumuşaması, Kircheimer'in herkesi yakala parti tipolojisinin Ak Parti için de geçerli olduğunu göstermiştir. Ak Parti, Millî Görüş geleneğinin İslamcı ideolojisinden uzaklaşarak muhafazakâr demokrat kimliği benimsemekle toplumun daha farklı ve geniş kesimlerini yakalama imkânına kavuşmuştur. Gerçekten de partinin oy oranlarına ve farklı seçimlerde farklı seçmen kitlelerinden aldığı oylara bakıldığında siyasal konjonktüre göre değişen pragmatist politikalarla seçmen sayısını artırdığı ve böylece hepsini yakala parti tipolojisini sergilediği görülecektir.

Türkiye'de parti sistemini etkileyen unsurların çeşitlilik göstermesi Ak Parti'nin konumunu etkilemektedir. Öncelikle seçim sistemi; parlamentoya girecek partilerin sayısında ve milletvekili dağılımında orantısız sonuçlara sebep olmaktadır. Buna ek olarak toplumda ideolojik bölünme çizgilerinin sayıca fazla olması ve bu ideolojik bölünme çizgileri arasında geçişkenliğin var olması, siyasi partilerin oylarında oynaklığa ve meclisteki temsilde parçalanmışlığa yol açmaktadır. Bu sebeple ülke barajının ve nispi temsil sisteminin etkisi, ideolojik bölünme çizgilerinin sayısı ve geçişkenliği parti sisteminde kalıcı bir duruma izin vermemektedir. Bu durumda Ak Parti'nin hepsini yakala parti tiplojisi sergilemesi ve farklı seçim dönemlerinde konjonktüre bağlı olarak farklı seçmen kitlelerini yakalamayı hedeflemesi daha anlaşılır hale gelmektedir.

Ak Parti'nin kurumsallaşma süreci ise dinamik bir niteliğe sahiptir. Öncelikle karizmatik bir lider tarafından kurulduğu günden beri yönetilmesi sebebiyle liderin yöneticilik vasfını çevreleyen karizması, partinin kurumsal kimliğinin önüne geçmiştir. Bu sebeple partinin kurumsallaşma sürecinin, kurucu lider sonrasında da devam edip etmeyeceğini kestirmek güçtür. Ancak geçen zaman dilimine bakıldığında, kapatma davasından 15 Temmuz darbe girişimine kadar parti, birçok tehdidin üstesinden gelerek kendini değişimlere karşı uyarlamıştır. Uzun vadeli politik hedefler ve yatırım programları geliştirerek fonksiyonelliğini seçmenin gözünde pekiştirmektedir. Parti örgütünde çeşitli alt birimleri kurup işleterek üyelerin politika yapma becerilerini geliştirme konusunda eğitmekte ve karar alma mekanizmalarının işleyişine adapte olmalarını sağlamaktadır. Ancak partinin karizmatik liderliği ve merkeziyetçi yapısı bu karar alma mekanizmalarının politika yapma konusundaki etkinliğini gölgelemektedir.

\section{KAYNAKÇA}

AKDOĞAN, Yalçın (2004), Ak Parti ve Muhafazakâr Demokrasi, Alfa Yayınları, İstanbul.

BORA, Tanıl (1998), Türk Sağının Üç Hali, Birikim Yayınları, İstanbul.

DURSUN, Davut (2008), Siyaset Bilimi, Beta Yayınları, İstanbul, 4. Baskı.

DUVERGER, Maurice (1974), Siyasi Partiler (Çev. Ergun Özbudun), Bilgi Yayınevi, Ankara, 2. Bask1

ERDOĞAN, Mustafa (2011), Türkiye'de Anayasalar ve Siyaset, Liberte Yayınları, Ankara, 8. Bask1.

ERDOĞAN, Recep Tayyip (2004), "Açılış Konuşması", Uluslararası Muhafazakarlık ve Demokrasi Sempozyumu Bildiri Kitabı, Ak Parti Yayını, Ankara, ss.7-14.

ERLER, Özgün (2007), "Yeni Muhafazakarlık, Akp ve 'Muhafazakar Demokrat' Kimlik”, Stratejik Öngörü Dergisi, S.(10), ss.126-132.

HUNTINGTON, Samuel P. (1966), "Siyasal Gelişme ve Siyasal Bozulma” (Çev. Ergun Özbudun), Ankara Üniversitesi Hukuk Fakültesi Dergisi, S.22(1), ss.55-107. 
KALAYCIOĞLU, Ersin (2008), "Attitudinal Orientation to Party Organization in Turkey in the 2000s." Turkish Studies, S.9(2), ss.297-316.

KAPANİ, Münci (2012), Politika Bilimine Giriş, Bilgi Yayınları, Ankara, 31. Bask1.

KATZ, Richard S. ve MAIR, Peter (1995), “'Changing Models of Party Organization and Part Democracy: The Emergence of the Cartel Party”, Party Politics, S.1(1), ss.5-28.

KIRCHEIMER, Otto (1966), "The Transformation of the Western European Party Systems", Political Parties and Political Development (Ed. Joseph La Palombara ve Myron Weiner), Princeton University Press, New Jersey, ss.177-200.

MICHELS, Robert (1915), Political Parties, Hearst's International Library, New York.

MILES, Matthew B. ve HUBERMAN, A. Michael (2015), Nitel Veri Analizi, Pegem Akademi, Ankara.

MOSCA, Gaetano (1939), The Ruling Class, Mc-Graw-Hill Book Company, New York.

NEUMANN, Sigmund (1956), "Toward a Comparative Study of Political Parties", Modern Political Parties (Ed. Sigmund Neumann), University of Chicago, Chicago, ss.395-400.

ÖZBUDUN, Ergun (1977), Siyasal Partiler, Ankara Üniversitesi Hukuk Fakültesi Yayını, Ankara.

ÖZBUDUN, Ergun (2003), Çağdaş Türk Politikası: Demokratik Pekişmenin Önündeki Engeller, Doğan Kitap, İstanbul.

ÖZBUDUN, Ergun (2015), Anayasacılık ve Demokrasi, İstanbul Bilgi Üniversitesi Yayını, İstanbul.

ÖZBUDUN, Ergun (2016), Türkiye'de Parti ve Seçim Sistemi, İstanbul Bilgi Üniversitesi Yayını, İstanbul, 2. Bask1.

ÖZBUDUN, Ergun ve HALE, William (2010), Türkiye'de İslamcılık, Demokrasi ve Liberalizm: AKP Olayı (Çev. Ergun Özbudun, Kadriye Göksel), Doğan Kitap, İstanbul.

ÖZIPEK, Bekir Berat (2004), "Muhafazakâr Siyasetin Temelleri", Uluslararası Muhafazakârlık ve Demokrasi Sempozyumu Bildiri Kitabı, Ak Parti Yayını, Ankara, ss.80-86.

PANEBIANCO, Angelo (1988), Political Parties: Organization and Power, Cambridge University, Cambridge.

PARETO, Vilfredo (1968), The Rise and Fall of The Elites: An Application of Theoretical Sociology, The Bedminister Press, New Jersey.

PUNCH, Keith F. (2014), Sosyal Araştırmalara Giriş: Nitel ve Nicel Yaklaşımlar (Çev. Dursun Bayrak, H. Bader Arslan, Zeynep Akyüz), Siyasal Kitabevi Yayınları, Ankara, 3. Baskı.

SARTORI, Giovanni (2005), Parties and Party Systems: A Framework for Analysis, Ecpr Press, Essex.

SAYARI, Sabri (2015), "Siyasi Partiler ve Parti Sistemleri", Karşılaştırmalı Siyaset: Temel Konular ve Yaklaşımlar (Der. Sabri Sayarı, Hasret Dikici Bilgin), İstanbul Bilgi Üniversitesi Yayınları, İstanbul, ss.123-143, 3. Bask1.

YANIK, Murat (2003), "Parti Sistemleri ve Türkiye Uygulamaları", Erzincan Binali Yıldırım Üniversitesi Hukuk Fakültesi Dergisi, S.7(1-2), ss.271-282.

http://www.akparti.org.tr/site/haberler/ak-partinin-uye-sayisi-10-milyona-yaklasmis-vaziyette/83323\#1 (Erişim Tarihi: 03.08.2020).

http://www.dunyabulteni.net/?aType=yazarHaber\&ArticleID=1869 (Erişim Tarihi: 10.08.2020).

https://www.akparti.org.tr/ak-kadro/mkyk/mustafa-atas/ (Erişim Tarihi: 10.08.2020).

https://www.akparti.org.tr/parti/2023-siyasi-vizyon/ (Erişim Tarihi: 10.12.2020).

https://www.akparti.org.tr/site/haberler/ak-parti-bir-kitle-partisidir/64162\#1 (Erişim Tarihi: 10.08.2020).

https://www.hurriyet.com.tr/gundem/erbakana-ilk-bayrak-39138765 (Erişim Tarihi: 10.12.2020).

https://www.resmigazete.gov.tr/eskiler/2002/11/20021110.htm\#5 (Erişim Tarihi: 10.12.2020). 